Article

\title{
On the Role of Grain Size and Carbon Content on the Sensitization and Desensitization Behavior of 301 Austenitic Stainless Steel
}

\author{
Satish Kolli * (1), Vahid Javaheri ${ }^{\circledR}$, Jukka Kömi and David Porter \\ Materials and Mechanical Engineering, Centre for Advanced Steels Research, University of Oulu, 90014 Oulu, \\ Finland; vahid.javaheri@oulu.fi (V.J.); jukka.komi@oulu.fi (J.K.); david.porter@oulu.fi (D.P.) \\ * Correspondence: satish.kolli@oulu.fi; Tel.: +358-503368628
}

Received: 14 October 2019; Accepted: 5 November 2019; Published: 6 November 2019

check for updates

\begin{abstract}
The effect of grain size in the range 72 to $190 \mu \mathrm{m}$ and carbon content in the range $0.105-0.073 \mathrm{wt} . \%$ on the intergranular corrosion of the austenitic stainless steel 301 has been investigated. Grain boundary chromium depletion has been studied directly using energy dispersive X-ray spectroscopy combined with scanning transmission electron microscopy and indirectly using double loop electrochemical potentiokinetic reactivation tests. In addition, chromium depletion has been modelled using the CALPHAD Thermo-Calc software TC-DICTRA. It is shown that the degree of sensitization measured using the double loop electrochemical potentiokinetic reactivation tests can be successfully predicted with the aid of a depletion parameter based on the modelled chromium depletion profiles for heat treatment times covering both the sensitization and de-sensitization or self-healing. Additionally, along with intergranular $\mathrm{M}_{23} \mathrm{C}_{6}$ carbides, intragranular $\mathrm{M}_{23} \mathrm{C}_{6}$ and $\mathrm{Cr}_{2} \mathrm{~N}$ nitrides that affect the available $\mathrm{Cr}$ for grain boundary carbide precipitation were also observed.
\end{abstract}

Keywords: sensitization; self-healing; Thermo-Calc; precipitation; diffusion; grain size

\section{Introduction}

Austenitic stainless steels have excellent corrosion resistance. However, they are susceptible to intergranular corrosion, that is, sensitization when exposed to the temperature regime $500-850{ }^{\circ} \mathrm{C}[1-3]$. This is due to the grain boundary precipitation and growth of chromium carbides that cause the formation of $\mathrm{Cr}$ depleted zones, resulting in intergranular corrosion. However, the degree of sensitization is not directly correlated to the amount of carbide precipitation. It depends on the details of the chromium concentration profiles in the vicinity of the grain boundaries.

It is common to measure the intensity of intergranular attack in environments that are considered corrosive such as acids. There are standardized tests that have been developed to compare sensitization resistance excluding the effect of the testing medium. These tests are defined by American Society for Testing and Materials (ASTM) standards that include electrochemical techniques such as the double loop electrochemical potentiokinetic reactivation (DL-EPR) test [4]. The composition of the electrolyte, temperature, potential limits and scan rate need to be determined for each alloy.

There are several works dealing with the experimental quantification of sensitization in austenitic stainless steels and extensive work has been done to understand the effects of different variables on the magnitude of the sensitization [5-8]. For example, the influence of time at sensitization temperatures [9], the effect of strain [10] and the effect of grain size on chromium carbide precipitation has been studied [11-13]. Models have also been developed for the prediction of carbide precipitation [14-16].

The model proposed by Stawström and Hillert [17] showed that the precipitation, sensitization and desensitization kinetics are proportional to the square of grain size. The time to reach self-healing 
was calculated by considering the critical concentration of chromium to be $13 \%$ by wt. In this model, basic rate equation is obtained using Fick's second law and the flux of chromium at the interface is obtained using mass balance theory in Zener's model. However, multicomponent effects are not considered in both thermodynamic and kinetic modelling in the work. Pascali et al. [18] studied the effect of carbon content and grain size on the sensitization kinetics. It was observed that increase in grain size delayed the sensitization and desensitization at lower temperatures. The major effect of increased carbon content is the lowering of maximum temperature at which Time-Temperature-Sensitization (TTS) can be observed. The discrepancies in sensitization results between different test methods ASTM A262 Practice E and electrochemical potentiokinetic reactivation (EPR) test did not allow any other conclusions to be withdrawn. Beltran et al. [19] studied the simultaneous effect of strain and grain size on the sensitization in 304 stainless steels. With decrease in grain size from 150 to $15 \mu \mathrm{m}$, at $625^{\circ} \mathrm{C}$, the time to sensitize decreased and the deformation effects became less apparent. It was observed that the combined effects are due to the superposition of grain size effects, that cause increase in grain boundary diffusion paths (with decrease in grain size) and strain effects that control the mechanism of diffusion. However, in the $15 \mu \mathrm{m}$ sample, the strain effects became less prominent and the grain size effects dominated the sensitization phenomenon. The work by Yu et al. [12] showed that the degree of sensitization (DOS) decreased with increasing solution annealing temperature and time that attributed to an increase in grain size. He used cellular automaton (CA) that describes the discrete spatial and temporal microstructure evolution on mesoscale to investigate intergranular corrosion (IGC) of austenitic stainless steel. Li et al. [11] also evaluated the influence of grain growth on the chromium carbide precipitation and showed that bulk chromium carbide precipitation kinetics are reduced with an increase in grain size. Yin et al. [20] predicted the effect of grain size on the chromium concentration profiles in Inconel 690. It was observed that larger grains resulted in lower minimum grain boundary chromium concentrations and wider chromium depleted zones and consequently lower sensitization resistance. Multicomponent effects are only considered to estimate the solubility data of carbon and chromium and not in other thermodynamic and diffusion calculations.

However, the effect of grain size on the electrochemical behaviour of intergranular corrosion has not been studied in the case of 301 SS. Also, the role of grain size and carbon content on the development and the characteristics of $\mathrm{Cr}$ depleted zones has not been extensively studied considering the multicomponent diffusion effects. Therefore, the present work concentrated on experimental and numerical studies of grain size and carbon content effects on the precipitation of chromium carbides, sensitization and self-healing in 301 stainless steels by taking into consideration, the multicomponent diffusion during the precipitate growth.

\section{Materials and Methods}

A 3 mm thick 301 austenitic stainless steel sheet with the chemical Fe-16.80Cr-6.36Ni-0.10C-0.065N (in wt.\%) provided by Outokumpu Stainless Oy Tornio, Finland has been studied. All the samples were initially solution treated (ST) at $1100^{\circ} \mathrm{C}$ for $2 \mathrm{~h}$ and water quenched for homogenization. Then, three sets of them were further annealed (A) at $1200^{\circ} \mathrm{C}$ for $2 \mathrm{~h}, 4 \mathrm{~h}$ and $8 \mathrm{~h}$ to produce varying grain sizes. This resulted in a total of 4 sets of material (along with ST) with varying grain sizes. Subsequently, all the 4 sets of samples were heat treated at $820^{\circ} \mathrm{C}$ for various times between 3 and $480 \mathrm{~h}$, as can be seen in Figure 1 and Table 1, to generate different levels of sensitization. The samples are coded following the format "Grain size / temperature in ${ }^{\circ} \mathrm{C}$-heat treatment time." For example, the sample condition ST $+1200{ }^{\circ} \mathrm{C} / 4 \mathrm{~h}$ heat treated at $820^{\circ} \mathrm{C}$ for $120 \mathrm{~h}$ will be referred as $120 \mu \mathrm{m} / 820{ }^{\circ} \mathrm{C}-120 \mathrm{~h}$ (the average grain size of the sample $\mathrm{ST}+1200^{\circ} \mathrm{C} / 4 \mathrm{~h}$ was $120 \mu \mathrm{m}$ ). 


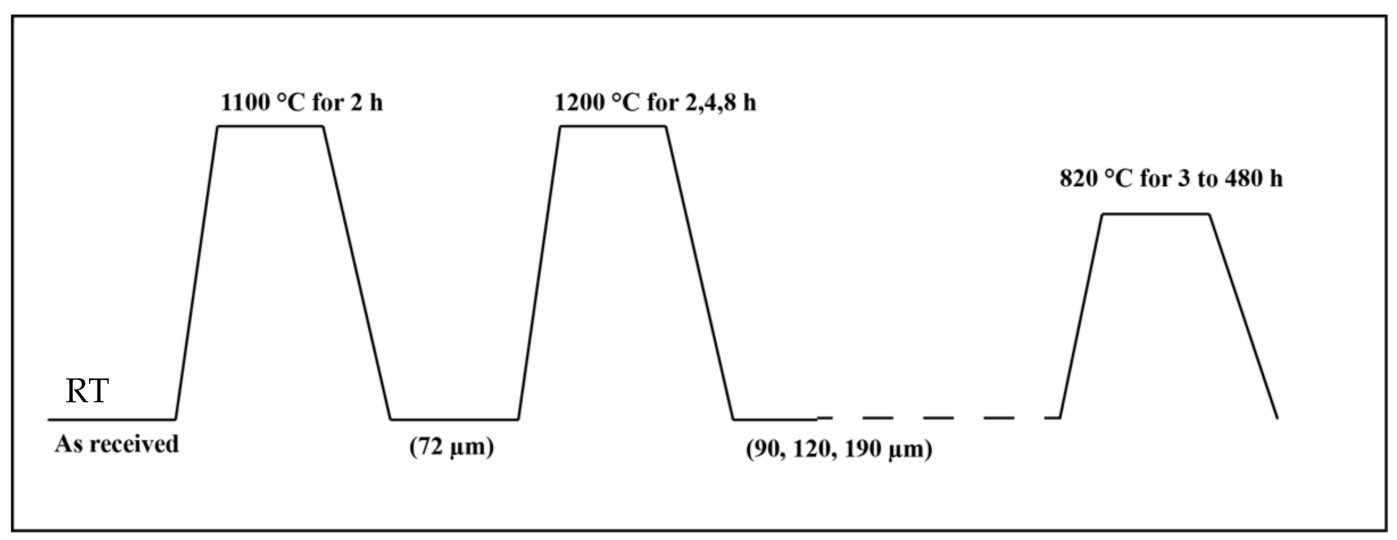

Figure 1. Heat treatments cycle employed.

Table 1. Heat treatments employed to generate varied grain sized materials with varying sensitization levels.

\begin{tabular}{cc}
\hline Heat Treatment & Heat Treatment Time at $820{ }^{\circ} \mathbf{C}$ (h) \\
\hline $1100{ }^{\circ} \mathrm{C} / 2 \mathrm{~h}(\mathrm{ST})$ & $3,10,24,48,120,168,240,480$ \\
$1200{ }^{\circ} \mathrm{C} / 2 \mathrm{~h}$ & $3,10,24,48,120,168,240,480$ \\
$1200{ }^{\circ} \mathrm{C} / 4 \mathrm{~h}$ & $3,10,24,48,120,168,240,480$ \\
$1200{ }^{\circ} \mathrm{C} / 8 \mathrm{~h}$ & $3,10,24,48,120,168,240,480$ \\
\hline
\end{tabular}

Field emission scanning electron microscopy (FESEM) (Zeiss Sigma, Carl Zeiss AG, Oberkochen, Germany) was used for metallographic investigation. The grain sizes were measured with the help of electron back scattered diffraction (EBSD) analysis. The EBSD mappings were performed using an accelerating voltage of $15 \mathrm{kV}$, a working distance of $15 \mathrm{~mm}$, a step size of $0.65 \mu \mathrm{m}$ and a tilt angle of $70^{\circ}$. In the measurement of grain sizes, the annealing twins are not counted as grains since they are not active sites for precipitation. The EBSD data were post-processed using MATLAB (version 2018b, MathWorks, Inc, Natick, MA, USA) supplemented with the MTEX toolbox [21].

All the heat treated samples were tested for sensitization using the double loop electrochemical potentiokinetic reactivation test (DL-EPR) according to the standard EN ISO 12732 [22]. This test gives the degree of sensitization as a percentage which was normalized with respect to the smallest grain sized sample used in this study, that is, $72 \mu \mathrm{m}$.

Normalized degree of sensitization (NDOS) $=I_{r} \times(\mathrm{GS} / 72)$, where $I_{r}$ is the maximum current for the reactivation loop $\left(\mu \mathrm{A} \cdot \mathrm{cm}^{-2}\right), I_{a}$ is the maximum current for the anodic loop $\left(\mu \mathrm{A} \cdot \mathrm{cm}^{-2}\right)$ and GS is the grain size of the specimen expressed as an equivalent circle diameter $(\mu \mathrm{m})$.

By normalizing the DOS values in this way, the effect of grain size on $I_{r}$ through the length of grain boundary sampled is compensated and the relative normalized values of DOS better describe the relative depletion effects across the grain boundaries.

These tests were carried out using a VersaStat 3 potentiostat (AMETEK Princeton Applied Research, Oak Ridge, TN, USA) using an electrochemical cell with three electrodes with a saturated calomel electrode (SCE) as the reference electrode, platinum as the counter electrode and the sample as the working electrode. The samples were polished to a 600 grit finish before the test. The electrolyte used was $0.5 \mathrm{M} \mathrm{H}_{2} \mathrm{SO}_{4}+0.01 \mathrm{M} \mathrm{KSCN}$ and the tests were run at ambient temperature with a scan rate of $6 \mathrm{~V} / \mathrm{h}$ having a potential range from 0 to $+400 \mathrm{mV}$ (SCE). Before the DL-EPR test, all the samples were maintained in the solution for $30 \mathrm{~min}$ to reach a steady state open-circuit potential. In this test, the polarization curve in the anodic direction (activation) and the corrosion current density associated with it corresponds to the corrosion across the whole specimen surface, while the corrosion current density observed during polarization in the cathodic direction (reactivation) corresponds to corrosion at the intersection of the grain boundaries with the surface [23]. Thus, the ratio of these two corrosion 
current densities gives a quantitative value of the degree of sensitization of the material. All of the experiments are repeated thrice and the observed DOS values are average values.

A $200 \mathrm{kV}$ energy filtered scanning transmission electron microscopy (JOEL JEM-2200FS EFTEM/STEM) (JOEL Ltd., Akishima, Kanto, Japan) was used for the detailed observation of grain boundaries and precipitates in the transmission and scanning transmission (STEM) modes. $0.1 \mathrm{~mm}$ thick wafers are made by polishing, from which $3 \mathrm{~mm}$ diameter transmission electron microscopy samples were punched. These were further ground to $0.08 \mathrm{~mm}$ before electropolishing at $25 \mathrm{~V}$ in an electrolyte consisting of perchloric acid, butyl cellosolve, ethanol and distilled water.

The growth of $\mathrm{M}_{23} \mathrm{C}_{6}$ grain boundary precipitates was modelled using TC-DICTRA (ThermoCalc 2019a, Solna, Sweden) a tool for simulating diffusion in multicomponent alloys [24]. The simulations were performed taking into consideration multicomponent effects $(\mathrm{Fe}, \mathrm{Cr}, \mathrm{Ni}, \mathrm{Si}, \mathrm{C}$ and $\mathrm{N})$ using the thermodynamic database TCFE7 and the mobility database of Thermo-Calc MOBFE2 [25]. It is assumed that $\mathrm{M}_{23} \mathrm{C}_{6}$ grows behind a planar austenite-carbide interface and thus the problem is reduced to one dimension. This seems justified as grain boundaries are expected to act as collector plates for the substitutional atoms that diffuse through the matrix to the grain boundaries since the mobility of substitutional alloying elements along the grain boundaries is much higher than through the austenite matrix [26]. The model used in the DICTRA simulations assumes local equilibrium at the precipitate-austenite interface and provides a numerical solution to the multi-component diffusion equations [24]. The composition at the interface between $\mathrm{M}_{23} \mathrm{C}_{6}$ carbide-austenite matrix is governed by the tie line that changes as the growth of the carbide proceeds. The activity of the carbon was assumed to be constant throughout the material owing to its higher diffusivity. The operative tie-line is then obtained by the iso-activity line for carbon that passes through the bulk composition of the material and thereby the initial interfacial concentrations. The determination of operating tie-line becomes difficult in multi-component systems. The iterative method to determine this operating tie line is mentioned in the work by Larsson et al. [27] and also employed by Kolli et al. [28]. The model initially considers the $\mathrm{M}_{23} \mathrm{C}_{6}$ carbide as an inactive phase and changes its status to active phase when there is enough thermodynamic potential for the formation for the phase. Automatic time step control is chosen for the simulations. In order to take into account the effect of soft-impingement, the width of the austenite from which $C$ can be withdrawn was taken to be one sixth of the grain size as suggested by Sourmail [29] and also employed by Kolli et al. [30] but additionally, the effect of taking the whole average equivalent circle diameter (ECD) grain size and half the ECD grain size were also simulated.

\section{Results}

\subsection{Equilibrium Calculations}

Heat treating austenite results in significant microstructural changes in the temperature ranges $500-900{ }^{\circ} \mathrm{C}$ that depend on the chemical composition, grain size and the exposure time. Precipitate phases nucleate on the high energy regions like the grain boundaries and grow. A phase diagram for the studied material calculated with the help of Thermo-Calc is presented in Figure 2a. For $0.1 \mathrm{wt} . \% \mathrm{C}$, the equilibrium phases in the sensitization temperature regime are austenite, $\mathrm{M}_{23} \mathrm{C}_{6}$ and $\mathrm{Cr}_{2} \mathrm{~N}$. All these phases have been observed in the microstructures of the different heat treatment conditions used in this work. The property diagram in the Figure $2 \mathrm{~b}$ shows the equilibrium number of moles of the phases in $100 \mathrm{~g}$ of alloy as a function of temperature. At the considered temperature $820{ }^{\circ} \mathrm{C}$, Thermo-Calc predicts the presence of chromium carbide $\left(\mathrm{M}_{23} \mathrm{C}_{6}\right)$ and chromium nitride $\left(\mathrm{Cr}_{2} \mathrm{~N}\right)$ and austenite under equilibrium conditions. 


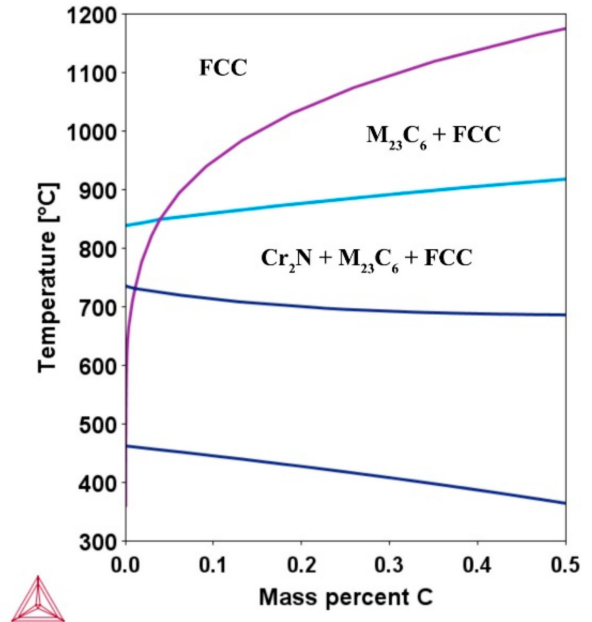

(a)

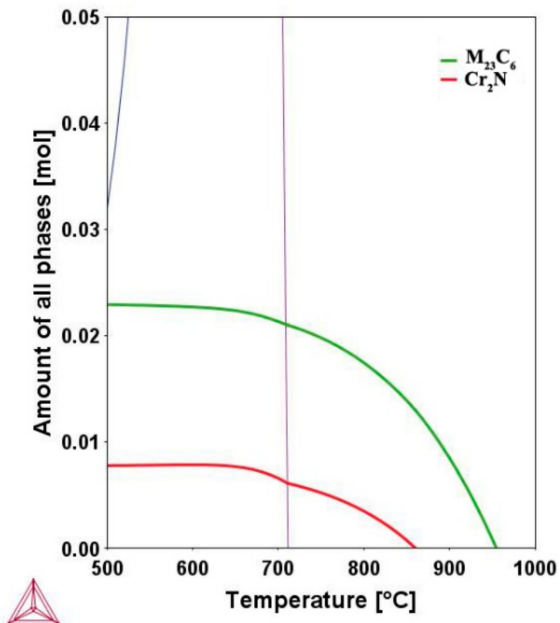

(b)

Figure 2. (a) Phase diagram showing the equilibrium phases in the experimental composition Fe-16.80Cr-6.36Ni-(0-0.5)C-0.065N (in wt.\%) (b) property diagram showing the amount of phases in the composition Fe-16.80Cr-6.36Ni-0.1C-0.065N.

\subsection{Grain Sizes}

Equivalent circle diameters (ECD) of the grains with a grain boundary misorientation angle $>15^{\circ}$ were obtained from the EBSD mappings using the MTEX toolbox. Figure 3 shows a typical microstructure as seen with an EBSD image for the sample condition ST $+1200^{\circ} \mathrm{C}$ for $4 \mathrm{~h}$.

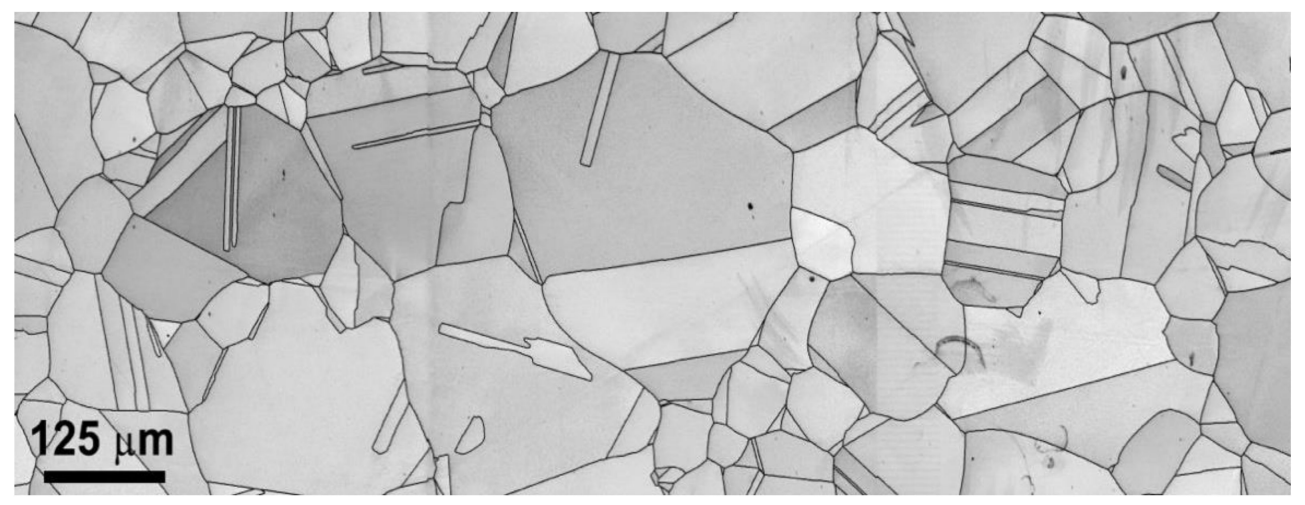

Figure 3. Microstructure observed under EBSD for $120 \mu \mathrm{m}$ sample condition.

The ST sample has the smallest grain size with an average ECD of $72 \mu \mathrm{m}$. The specimen conditions $\mathrm{ST}+1200^{\circ} \mathrm{C}$ for $2 \mathrm{~h}, 4 \mathrm{~h}, 8 \mathrm{~h}$ have average ECD values of 90,120 and $190 \mu \mathrm{m}$ respectively. Glow discharge optical emission spectroscopy of the specimens at the depth used for the DL-EPR tests revealed that the samples heat treated at $1200{ }^{\circ} \mathrm{C}$ to obtain increased grain sizes suffered some decarburization as can be seen in Table 2.

Table 2. Average grain equivalent circle diameters (ECD) and $C$ contents in the samples after the heat treatment.

\begin{tabular}{ccc}
\hline Sample Condition & Average Grain ECD $(\mu \mathrm{m})$ & C Content $(w t . \%)$ \\
\hline $1100^{\circ} \mathrm{C} / 2 \mathrm{~h}(\mathrm{ST})$ & $72 \pm 5$ & 0.105 \\
$\mathrm{ST}+1200^{\circ} \mathrm{C} / 2 \mathrm{~h}$ & $90 \pm 4$ & 0.085 \\
$\mathrm{ST}+1200^{\circ} \mathrm{C} / 4 \mathrm{~h}$ & $120 \pm 3$ & 0.082 \\
$\mathrm{ST}+1200^{\circ} \mathrm{C} / 8 \mathrm{~h}$ & $190 \pm 4$ & 0.073 \\
\hline
\end{tabular}




\subsection{Precipitates and Chromium Depletion}

\subsection{1. $\mathrm{M}_{23} \mathrm{C}_{6}$}

For the condition $72 \mu \mathrm{m} / 820^{\circ} \mathrm{C}-120 \mathrm{~h}$, Figure 4 shows precipitates on grain boundaries together with EDS mappings and elemental concentration profiles. The EDS analyses of the precipitates confirm that the observed precipitates are $\mathrm{M}_{23} \mathrm{C}_{6}$ carbides. According to the DL-EPR measurements that are shown in the later sections, this sample condition was completely self-healed. The concentration profiles along the red lines in Figure $4 \mathrm{~b}$ are shown in Figure $4 \mathrm{c}, \mathrm{d}$. Even though the $\mathrm{Cr}$ concentration right at the carbide-austenite interface cannot be seen due to the inclination of the interface with respect to the electron beam, the profiles indicate that the $\mathrm{Cr}$ concentration in the vicinity of the grain boundary carbides does not go below $12 \mathrm{wt} . \%$. The chromium depleted occurring during the sensitization phase has been partially replenished.

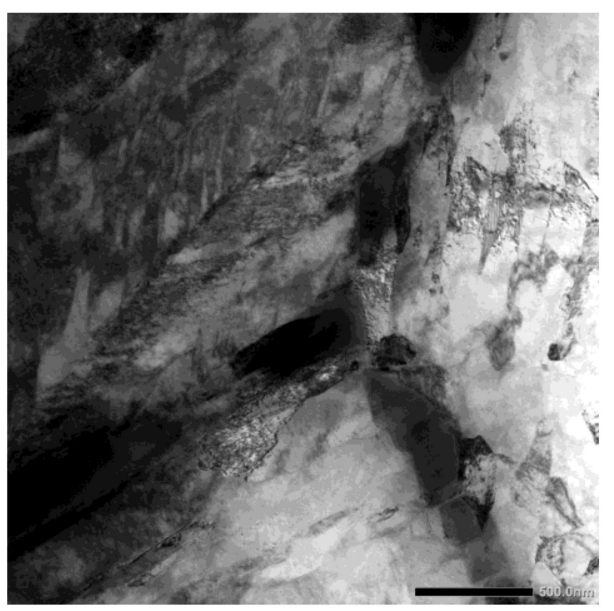

(a)

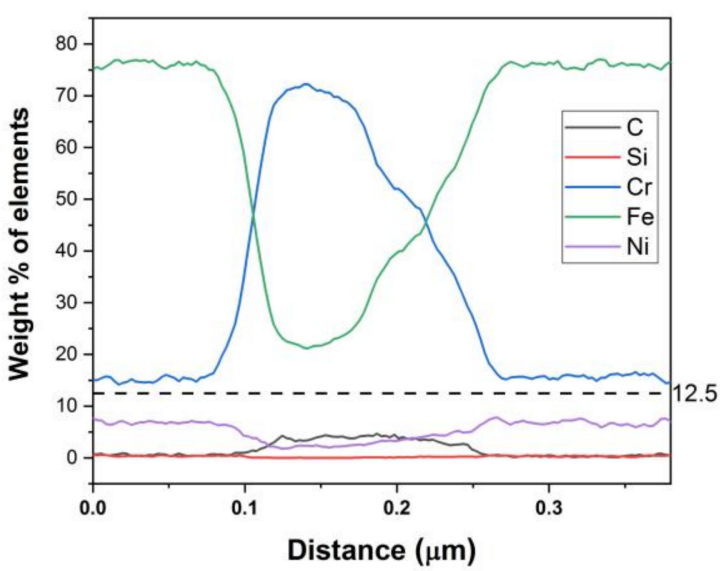

(c)

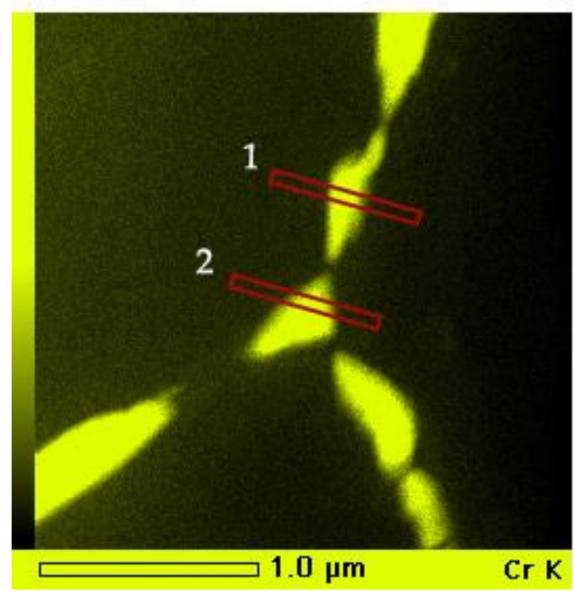

(b)

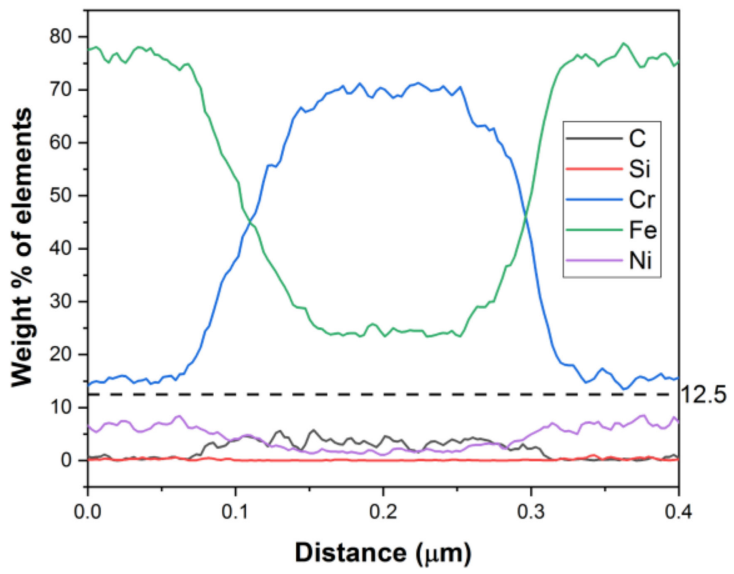

(d)

Figure 4. Sample $72 \mu \mathrm{m} / 820^{\circ} \mathrm{C}-120 \mathrm{~h}$. (a) Bright field transmission electron microscope (TEM) micrograph showing $\mathrm{M}_{23} \mathrm{C}_{6}$ carbides along a grain boundary. (b) EDS mapping of $\mathrm{Cr}$. (c,d) Concentration profiles along lines 1 and 2 in the Cr EDS map.

Besides intergranular precipitates that form at relatively short times, after long heat treatments, intragranular precipitates were also observed. Figure 5 shows bright field transmission electron microscopy (TEM) micrographs together with $\mathrm{Cr}$ mappings and $\mathrm{Cr}$ concentration profiles for intragranular $\mathrm{M}_{23} \mathrm{C}_{6}$ carbides formed in samples $120 \mu \mathrm{m} / 820{ }^{\circ} \mathrm{C}-168 \mathrm{~h}$ and $190 \mu \mathrm{m} / 820{ }^{\circ} \mathrm{C}-240 \mathrm{~h}$. Again, it can be seen that the $\mathrm{Cr}$ concentration in the vicinity of the carbide did not go below $12 \mathrm{wt} . \%$. 


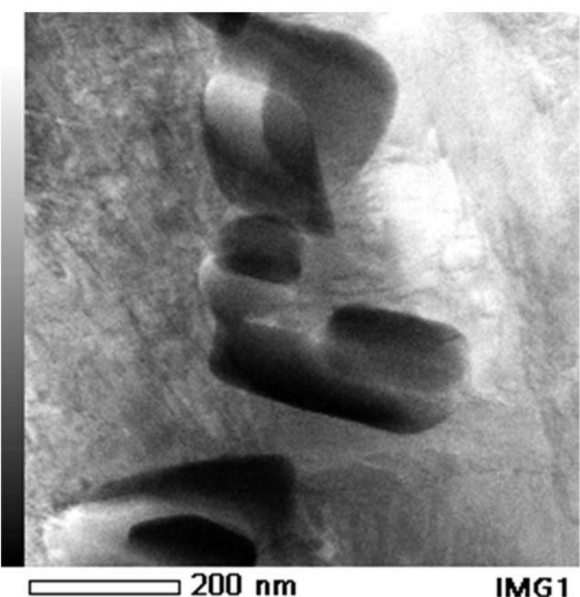

(a)

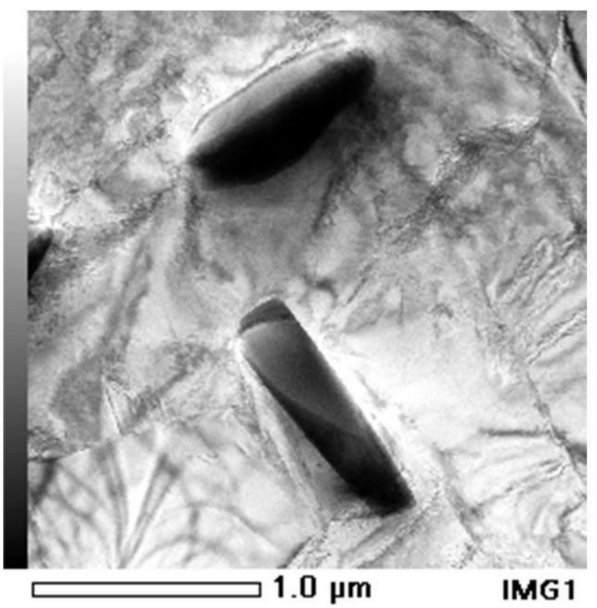

(c)

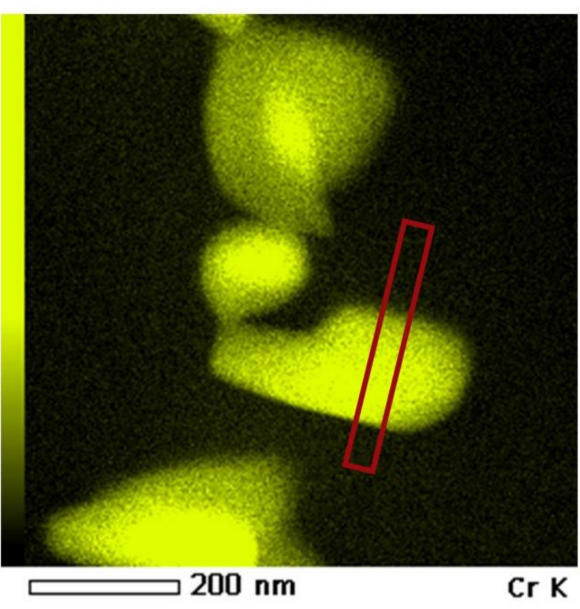

(b)

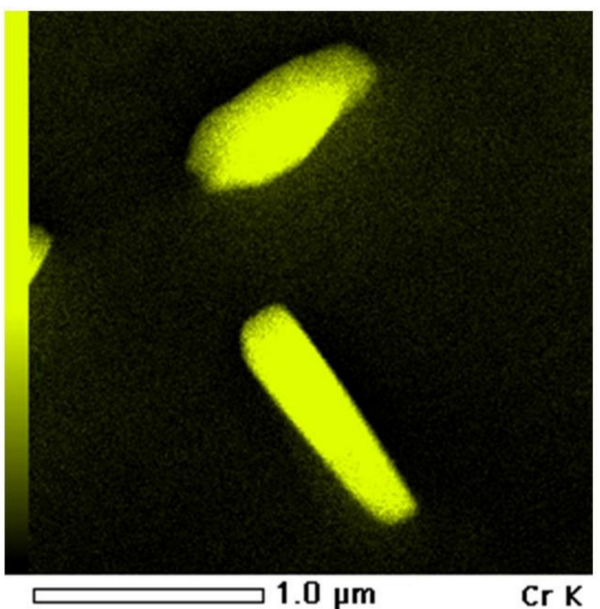

(d)

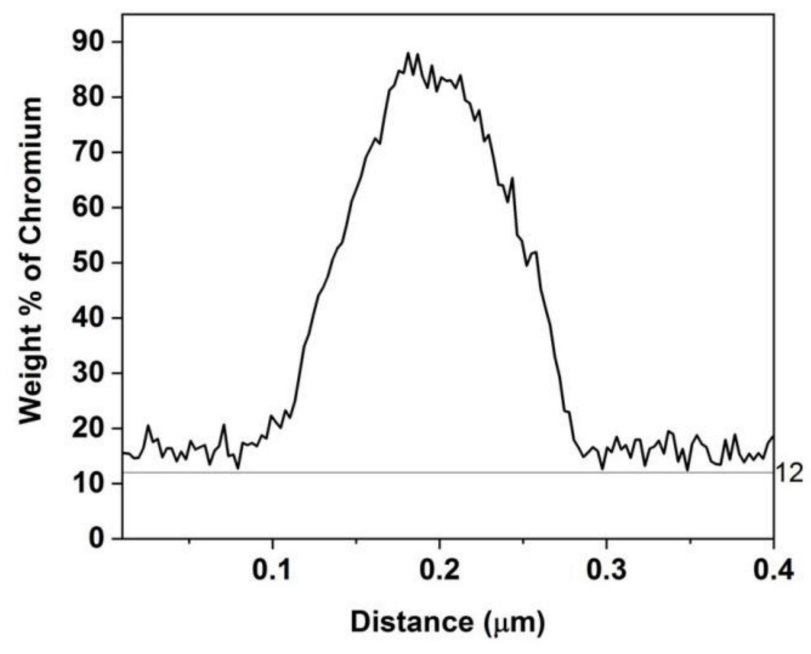

(e)

Figure 5. (a,c) Bright field Transmission electron microscopy (TEM) micrograph of $120 \mu \mathrm{m} / 820{ }^{\circ} \mathrm{C}-168 \mathrm{~h}$ and $190 \mu \mathrm{m} / 820^{\circ} \mathrm{C}-240 \mathrm{~h}$ respectively showing intragranular $\mathrm{M}_{23} \mathrm{C}_{6}$ carbides. (b,d) Energy dispersive spectroscopy (EDS) mapping of $\mathrm{Cr}$ for the micrographs $(\mathbf{a}, \mathbf{c})$ respectively, (e) $\mathrm{Cr}$ concentration profile along the red line shown in (b). 


\subsection{2. $\mathrm{Cr}_{2} \mathrm{~N}$}

In the case of the large grained samples $(120,190 \mu \mathrm{m})$ that are heat treated for a long time at $820^{\circ} \mathrm{C}(240 \mathrm{~h})$, chromium nitride precipitates are observed. Figure 6 shows a STEM image of such precipitates $\left(190 \mu \mathrm{m} / 820^{\circ} \mathrm{C}-240 \mathrm{~h}\right)$ together with a selected area electron diffraction (SAD) pattern of one of the precipitates revealing the fact that it was $\mathrm{Cr}_{2} \mathrm{~N}$ with a hexagonal crystal structure. A point analysis at the blue spot in Figure 6a revealed the precipitate composition to be $10.52 \mathrm{~N}-82 \mathrm{Cr}-3 \mathrm{Fe}$ (wt.\%). $\mathrm{Cr}$ depletion below that of the bulk is observed but the depleted $\mathrm{Cr}$ profiles did not go below $12 \%$.

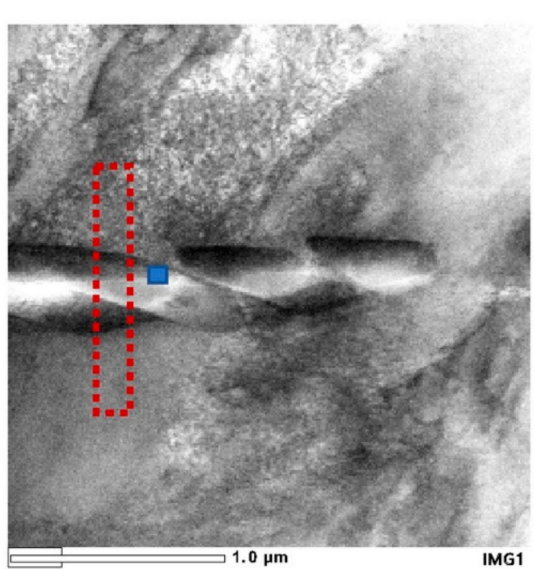

(a)

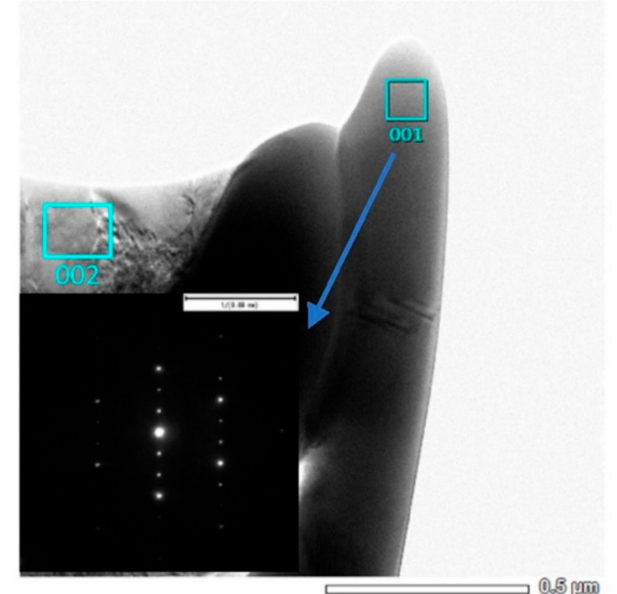

(b)

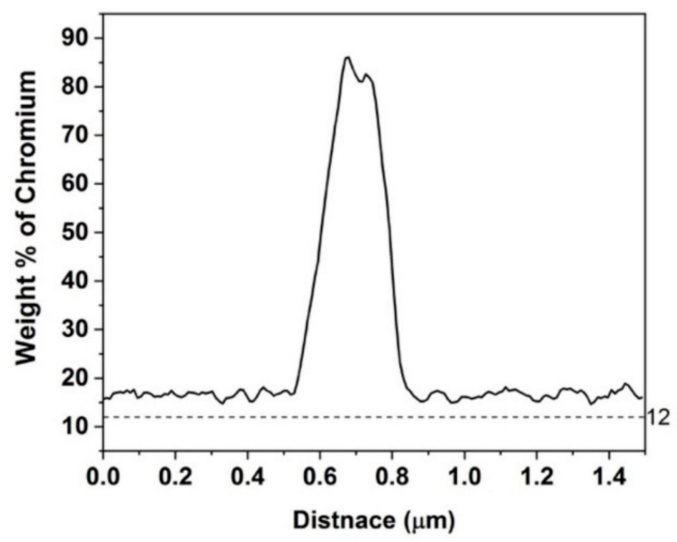

(c)

Figure 6. Sample $190 \mu \mathrm{m} / 820^{\circ} \mathrm{C}-240 \mathrm{~h}$ (a) STEM micrograph, (b) SAD pattern showing the precipitate to be $\mathrm{Cr}_{2} \mathrm{~N}$ and (c) $\mathrm{Cr}$ concentration profile along the red line shown in (a).

\subsection{Degree of Sensitization}

Figure 7 shows normalized DOS values (NDOS) obtained from the DL-EPR test results on the samples heat treated for various times. The normalization of the DOS values was done using average grain size obtained from the mean ECD grain sizes as described above. It can be seen that even after normalization, which compensates the reduction in the specific grain boundary length as grain size increases, an increase in grain size generally leads to a lower normalized degree of sensitization during both the sensitization and self-healing phases. The ST sample with a grain size of $72 \mu \mathrm{m}$ became highly sensitized with a high peak DOS. As the $C$ content is lower in large grained samples, the $C$ available for $\mathrm{M}_{23} \mathrm{C}_{6}$ formation is lower and thereby lower peak NDOS values are observed in these samples. Also, with decrease in $\mathrm{C}$ content, the nose of temperature-time-sensitization diagram shifts towards right and to lower temperatures $[10,31]$. So, the temperature at which peak NDOS can be observed 
will be lower for the sample conditions $90-190 \mu \mathrm{m}$. This is the reason for the decrease in NDOS with an increase in grain size from $72-190 \mu \mathrm{m}$.

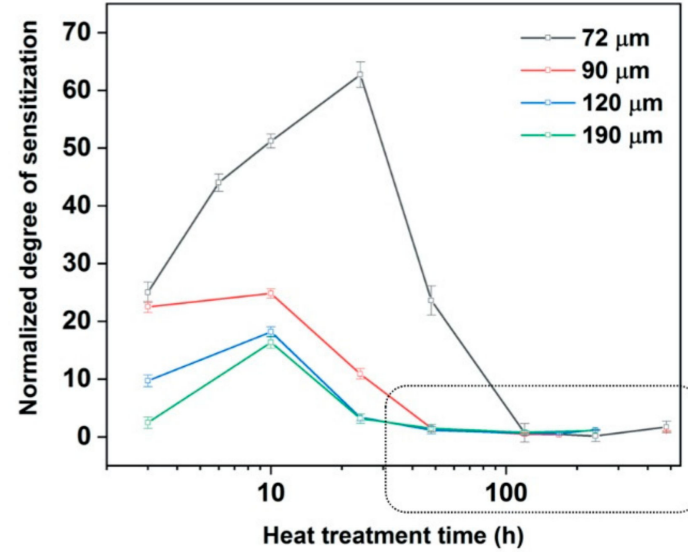

(a)

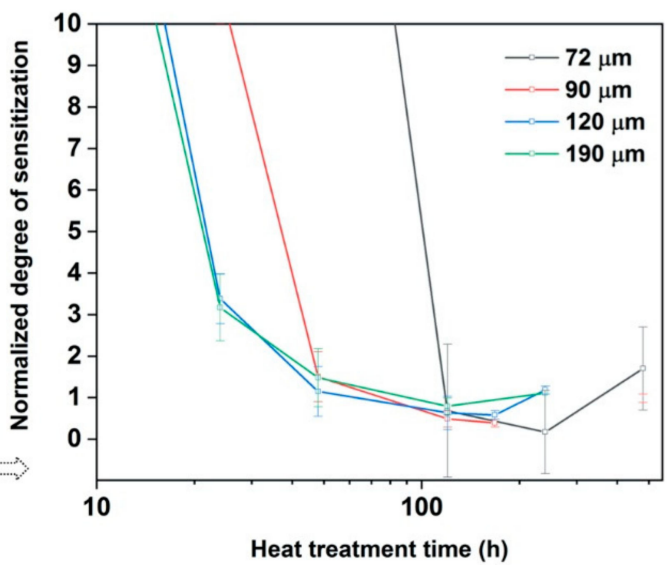

(b)

Figure 7. Normalized Degree of sensitization (NDOS) with heat treatment time at $820^{\circ} \mathrm{C}$. (a) all results, (b) results from beyond $20 \mathrm{~h}$ on an expanded scale. Means and standard deviations shown by points and error bars.

It can be observed that with an increase in grain size and reduction in carbon content the time to reach the peak NDOS is reduced. Figure $7 \mathrm{~b}$ shows that after heat treating the samples with mean grain sizes 120 and $190 \mu \mathrm{m}$ for $240 \mathrm{~h}$, a small increase in NDOS is observed. However, the increase is small compared to the scatter in the measured values.

\section{Modelling the Growth of Carbides}

The TC-DICTRA simulations of the growth of $\mathrm{M}_{23} \mathrm{C}_{6}$ were performed taking into consideration the multicomponent effects $(\mathrm{Fe}, \mathrm{Cr}, \mathrm{Ni}, \mathrm{Si}, \mathrm{C}$ and $\mathrm{N})$ using the thermodynamic database TCFE7 and the mobility database inside Thermo-Calc, MOBFE2. In the thermodynamic database, the $\mathrm{M}_{23} \mathrm{C}_{6}$ is treated as stoichiometric and diffusion inside the carbide is not considered.

The growth problem is reduced to one dimension by assuming that $\mathrm{M}_{23} \mathrm{C}_{6}$ grows into austenite behind a planar interface as shown in Figure 8, at any given time during the growth of $\mathrm{M}_{23} \mathrm{C}_{6}$ carbide. It was also assumed that the initial width of austenite from which $C$ can be withdrawn $\left(d_{a}\right)$ is $1 / 6$ th of the average $\operatorname{ECD}\left(d_{a}\right.$ changes with time). As discussed below, other assumptions regarding $d_{a}$ produced unsatisfactory models. The value of $d_{p}$ (carbide thickness) is considered to be zero at the start of carbide growth. It is also assumed that the nucleation time for grain boundary $\mathrm{M}_{23} \mathrm{C}_{6}$ is negligible such that growth starts as soon as the isothermal temperature is reached, that is, at zero time.

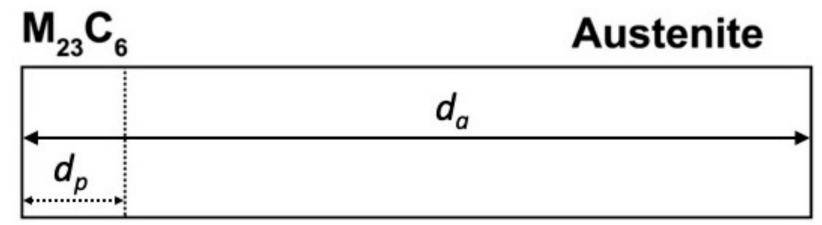

Figure 8. Treatment of numerical simulation across the carbide-austenite interface.

The growth simulations give the concentration profiles of all the alloying elements into the austenite matrix away from the carbide-austenite interface. For simplicity, we only consider the $\mathrm{Cr}$ concentration profiles. The $\mathrm{Cr}$ depletion adjacent to the precipitate can be characterized by three parameters: the $\mathrm{Cr}$ concentration in the matrix at the carbide-matrix interface $\left(\mathrm{Cr}_{\text {int }}\right)$, the critical concentration of $\mathrm{Cr}$ at which the width of depletion zone is measured $\left(\mathrm{Cr}_{\text {crit }}\right)$ and the width of 
the depleted zone $\left(W_{c r i t}\right)$ at $\mathrm{Cr}_{\text {crit }}$. Figure 9 shows the $\mathrm{Cr}$ concentration profiles obtained from the simulations. The $C r_{\text {int }}$ at $3 \mathrm{~h}$ is increasing from 10.61 to 11.87 with increase in grain size from 72 to $190 \mu \mathrm{m}$. (Figure 10b). If the $\mathrm{C}$ content is kept constant, the $C r_{\text {int }}$ should decrease with increase in grain size. In the case of a fixed bulk $\mathrm{C}$ content, due to the higher diffusion cell size $\left(d_{a}\right)$ the total mass of $\mathrm{C}$ available for the precipitation of $\mathrm{M}_{23} \mathrm{C}_{6}$ is higher in the case of large grain samples and thereby lower $\mathrm{Cr}$ concentrations in the austenite are predicted at the carbide-austenite matrix interface $\left(\mathrm{Cr}_{\text {int }}\right)$. On the other hand, for a fixed grain size (and $d_{a}$ ), lowering the bulk $\mathrm{C}$ content is predicted to increase $C r_{i n t}$. In the present case, the combined effect of increasing grain size in the range 72-190 $\mu \mathrm{m}$ and the concomitant partial decarburization leads to an increase in $\mathrm{Cr}_{\text {int }}$ at the start of the precipitation, that is, the lowering of the $\mathrm{C}$ content is predicted to dominate over the increase of grain size.

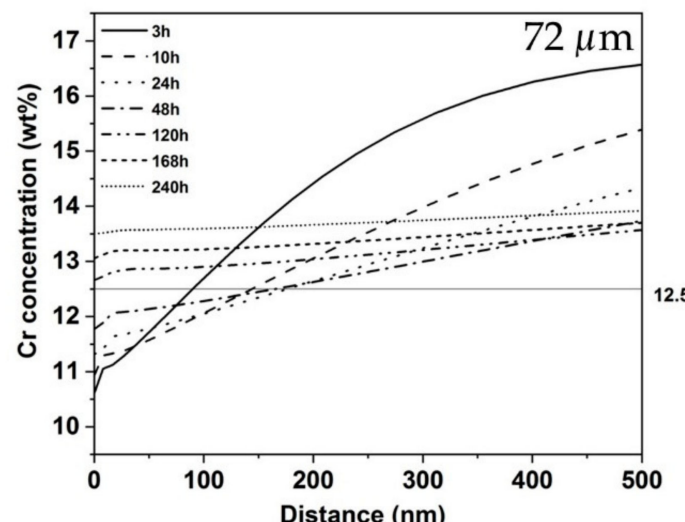

(a)

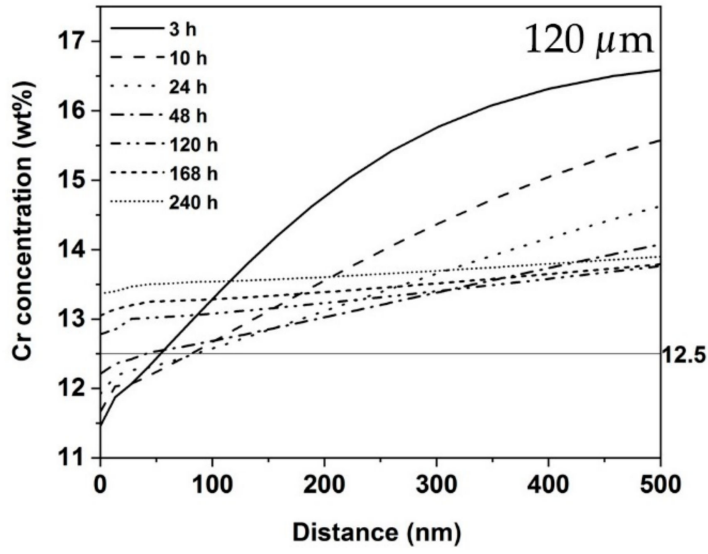

(c)

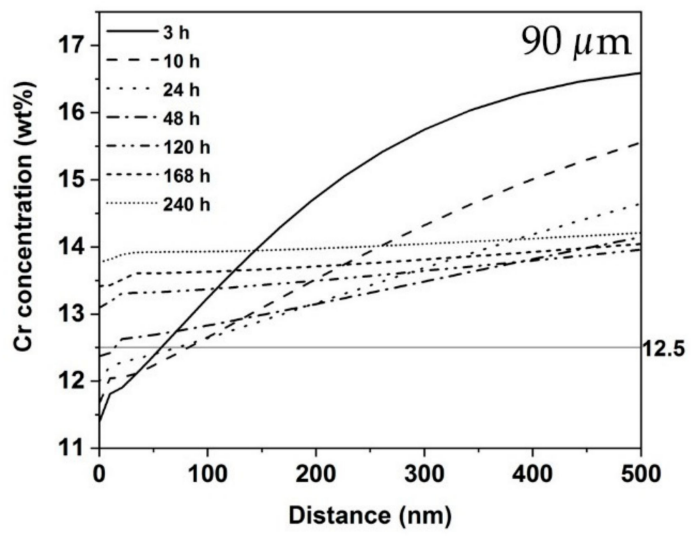

(b)

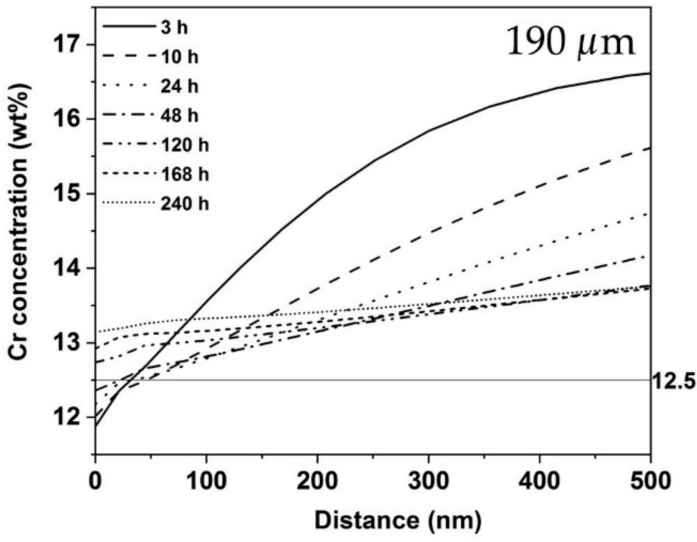

(d)

Figure 9. $\mathrm{Cr}$ concentration profiles in the austenite away from the $\mathrm{M}_{23} \mathrm{C}_{6}$ carbide-austenite matrix interface for the grain sizes (a) 72, (b) 90, (c) 120 and (d) $190 \mu \mathrm{m}$. 


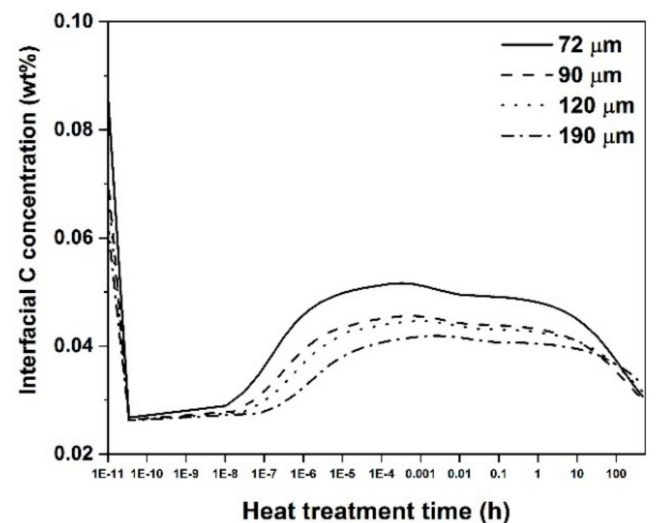

(a)

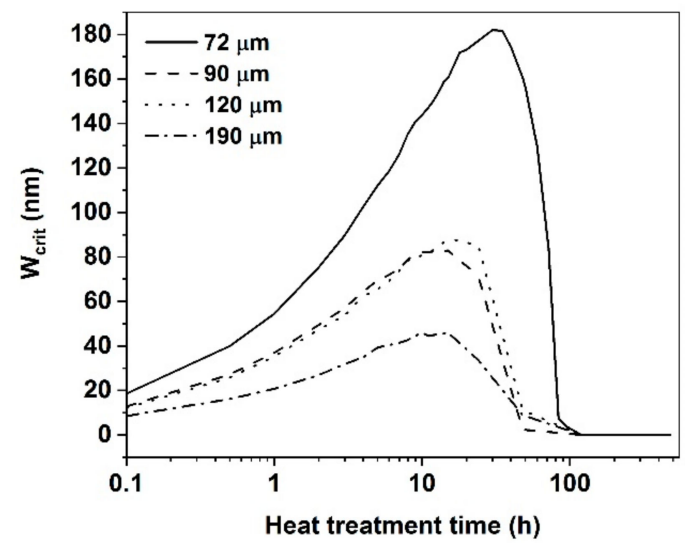

(c)

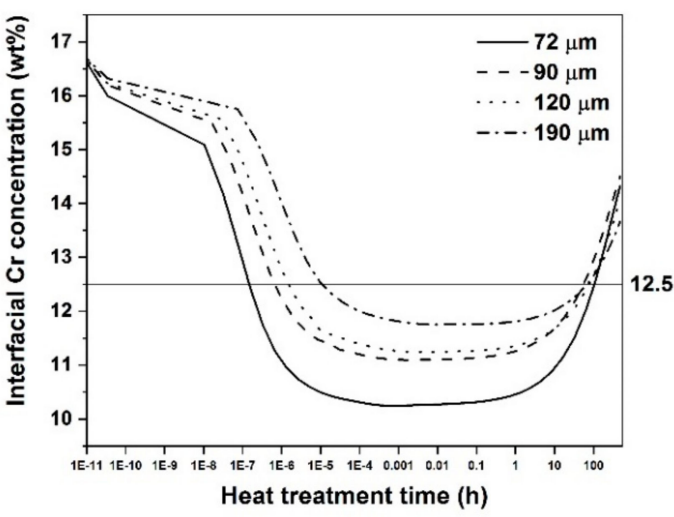

(b)

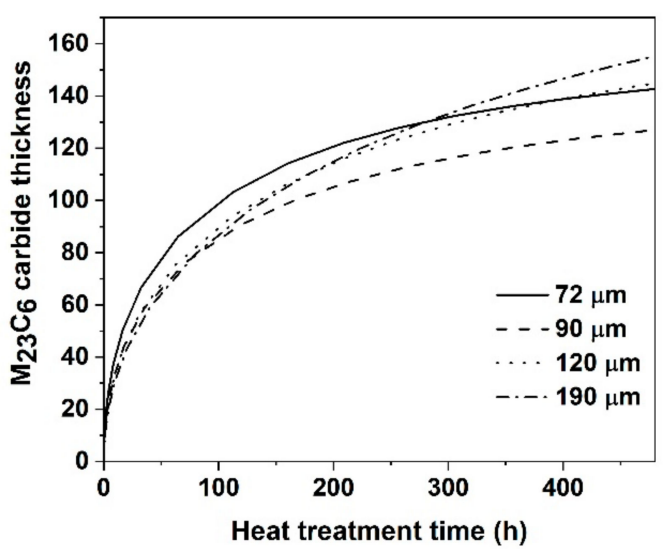

(d)

Figure 10. Variation of (a) interfacial $C(\mathbf{b})$ interfacial $\mathrm{Cr}$ in austenite at carbide-austenite interface (c) width of $\mathrm{Cr}$ concentration profile at $C r_{\text {crit }}(\mathrm{d})$ thickness of $\mathrm{M}_{23} \mathrm{C}_{6}$ carbide with heat treatment time.

\section{Discussion}

Li et al. [12] and Taiwade et al. [32] showed that the DOS decreases with increase in grain size. The measured NDOS values from Figure 7 also show the same, although large grained samples contain lower amounts of carbon. The exact time periods for the sensitization and desensitization were not measured and the varying carbon content in the samples with grain size did not permit in verifying grain size- sensitization relations proposed by Stawström and Hillert [17].

Sensitized microstructures have been well characterized previously $[33,34]$. The precipitation of $\mathrm{M}_{23} \mathrm{C}_{6}$ carbides occurs mainly on random high-angle grain boundaries and their size and spacing vary from boundary to boundary. From the TEM results of the self-healed sample shown in Figure 4, $\mathrm{Cr}$ depletion is observed in the vicinity of grain boundary $\mathrm{M}_{23} \mathrm{C}_{6}$ carbides but the $\mathrm{Cr}$ content did not go below $12 \mathrm{wt} . \%$. This is also the case for intragranular $\mathrm{M}_{23} \mathrm{C}_{6}$ carbides shown in Figure 5. In the samples where sensitization is prevalent, $\mathrm{Cr}$ concentrations have been found to go below $12 \mathrm{wt} . \%$ [35].

It is possible to perceive of various depletion parameters based on the terms $\mathrm{Cr}_{\text {int }}, \mathrm{Cr}_{\text {crit }}$ and $W_{\text {crit }}$ obtained from diffusion calculations. Three such depletion parameters are $\left(C r_{\text {crit }}-C r_{\text {int }}\right) \times W_{\text {crit }}$, $\left(C r_{\text {crit }} / C r_{\text {int }}\right) \times W_{\text {crit }}$ and $W_{\text {crit }} / C r_{\text {int }}$. The statistical analyses of the correlations between the experimentally measured DOS values and these potential depletion parameters based on a variety of definitions of $C r_{c r i t}$ showed that the best correlation is obtained with the following depletion parameter (DP):

$$
D P=\left(12.5-C r_{\text {int }}\right) \times W_{\text {crit }}, C r_{\text {int }}>10.0 \text { and }(12.5-10.0) \times W_{\text {crit }}, C r_{\text {int }} \leq 10.0
$$


i.e., using $W_{\text {crit }}$ values defined by $C r_{\text {crit }}=12.5 \%$. The statistical analyses showed that the best predictive power of the depletion parameter was obtained by setting a minimum value of $10 \mathrm{wt} . \%$ for $C r_{\text {int }}$. This implies that $\mathrm{Cr}$ contents in the depleted zone below $10.0 \mathrm{wt} . \%$ have no extra effect on the tendency to intergranular corrosion and measured DOS values. It has been shown earlier [25] that the same depletion parameter $(D P)$ is successful in predicting the sensitization and self-healing in austenitic stainless steel.

The final regression analysis of the experimental NDOS values based on the above definition of $D P$ resulted in the linear relation.

$$
\mathrm{NDOS}_{\text {predicted }}=0.23 \times D P
$$

that had an $R^{2}$ value of 0.85 , which is reasonable considering the simplicity of the model and also ignores the effects of intragranular precipitation, for example. Figure 11 shows the variation of calculated $D P$ with measured NDOS values. The appearance of the intragranular $\mathrm{M}_{23} \mathrm{C}_{6}$ and $\mathrm{Cr}_{2} \mathrm{~N}$ precipitates after long healing times will also affect the $\mathrm{Cr}$ profiles in the vicinity of the grain boundary carbides but such effects are excluded from the simple model. The small increase in DOS after $168 \mathrm{~h}$ observed in all the sample conditions could not be predicted by this simple model.

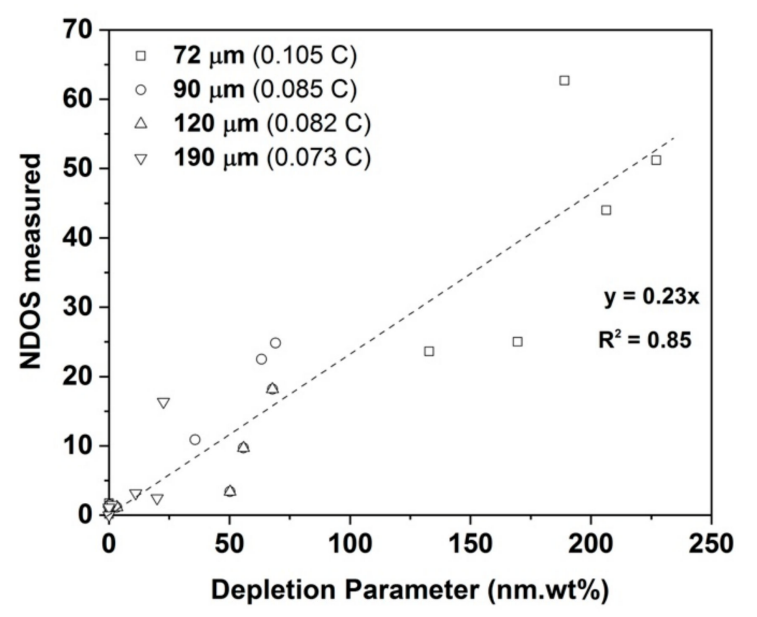

Figure 11. Predicted $D P$ values to experimentally measured NDOS values.

Nevertheless, the model is quite good at predicting the trends of the measured NDOS values for the conditions considered. Regarding the effect of heat treatment time at $820^{\circ} \mathrm{C}$ on the sensitization and self-healing kinetics, Figure 11 shows that the predicted NDOS values follow the same trend as the experimentally measured values. The peak NDOS $_{\text {predicted }}$ is in accordance with the experimentally measured NDOS values. The higher peak NDOS predicted has been observed in $72 \mu \mathrm{m}$ with higher $\mathrm{C}$ content. The available $\mathrm{C}$ for the precipitation of $\mathrm{M}_{23} \mathrm{C}_{6}$ carbide is lower in the case of samples with lower $\mathrm{C}$ content. It can be seen from Figure $10 \mathrm{~b}, \mathrm{c}$ after $3 \mathrm{~h}$ heat treatment, $\mathrm{C} r_{\text {int }}$ is higher and $\mathrm{W}_{\text {crit }}$ lower in the $190 \mu \mathrm{m}$ sample than the $72 \mu \mathrm{m}$ sample. This is due to the lower $\mathrm{C}$ content of the $190 \mu \mathrm{m}$ sample leading to thinner grain boundary carbide, see Figure 10d. The variation of $C r_{\text {int }}$ and $W_{\text {crit }}$ controls how the DP changes and affects the predicted NDOS. In Figure 10b, when $\mathrm{Cr}_{\text {int }}$ reaches above $12.5 \% \mathrm{Cr}$, implies the sample condition is completely self-healed.

A good correlation between measured NDOS values and DP was only found when $d_{a}$ was considered to be $1 / 6^{\text {th }}$ of the average grain ECD and not if it was taken to be the full average grain ECD or half of the average. This supports the earlier assumptions regarding $d_{a}$ made by Sourmail [29] and Kolli [30]. The approach is based on the idea that grains are taken as cubes with six faces making it appropriate to attribute to each calculation volume a sixth of the grain diameter from which $\mathrm{C}$ and $\mathrm{Cr}$ can be drawn. The predicted NDOS has been plotted with heat treatment time in Figure 12. It can be seen that the peak NDOS along with the time to reach peak NDOS are decreasing with increase in 
grain size and decrease in carbon content. The calculated NDOS values follow the similar trend to the measured NDOS values from Figure 7.

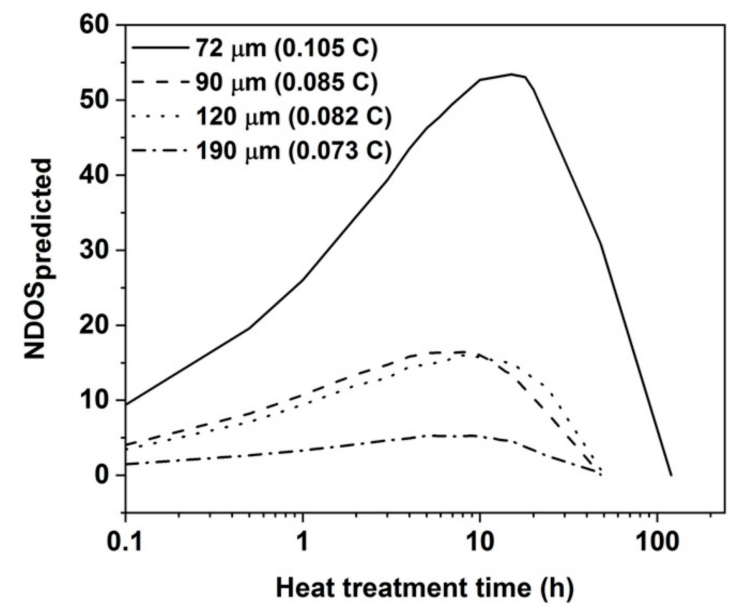

Figure 12. NDOS predicted with time for all the sample conditions.

\section{Summary and Conclusions}

An austenitic stainless steel with the composition Fe-16.80Cr-6.36Ni-0.105C-0.06N has been solution treated at $1100{ }^{\circ} \mathrm{C}$ and $1200{ }^{\circ} \mathrm{C}$ and quenched to produce various grain sizes in the range $72-190 \mu \mathrm{m}$ and corresponding carbon contents in the range $0.105-0.073 \mathrm{wt} . \%$. Carbon content decreased with increasing grain size due to the longer times needed at $1200^{\circ} \mathrm{C}$ to produce the larger grain sizes. The samples were further heat treated isothermally at $820^{\circ} \mathrm{C}$ for times in the range $3 \mathrm{~h}$ to $480 \mathrm{~h}$, which induced various degrees of sensitization and self-healing. The degree of sensitization was measured using DL-EPR tests and normalized to account for the effect of grain size on grain boundary length in the tested area. $\mathrm{M}_{23} \mathrm{C}_{6}$ grain boundary precipitates were identified using transmission electron microscopy. Chromium depletion profiles were calculated using Thermo-Calc DICTRA software and used to define a chromium depletion factor based on the predicted chromium concentration at the interface and the width of the profile at the critical chromium content of $12.5 \mathrm{wt} . \%$. A good correlation between the depletion parameter and the normalized degree of sensitization was obtained when conditions are set regarding the lowest interface chromium concentration. The work shows that the depletion parameter based on concentration profiles obtained using DICTRA can quite successfully predict the degree of sensitization both during the sensitization stage and the self-healing stage. Deviations from the predictions may be have been partly caused by the appearance of intragranular $\mathrm{M}_{23} \mathrm{C}_{6}$ and $\mathrm{Cr}_{2} \mathrm{~N}$ precipitates that were observed after long heat treatment times at $820^{\circ} \mathrm{C}$ but that were not included in the one-dimensional DICTRA model.

Author Contributions: Writing-original draft, S.K.; writing—review and editing, S.K., V.J., J.K. and D.P.; supervision, D.P., resources, J.K. and D.P.

Funding: This project has received funding from the European Union's Horizon 2020 research and innovation programme under the Marie Skłodowska-Curie grant agreement No 675715.

Acknowledgments: The authors would like to thank Thomas Ohligschläger of Tornio R\&D Center, Outokumpu with regards to providing material and heat treatments. The authors thank Tun Tun and Sami Saukko for their support with regards to TEM work. The support of Outokumpu stainless Oy, Tornio in providing the material is also acknowledged.

Conflicts of Interest: The authors declare no conflict of interest. 


\section{References}

1. Sedriks, A.J. Corrosion of Stainless Steels, 2nd ed.; Wiley: Hoboken, NJ, USA, 1996; p. 112.

2. Hänninen, H.E. Influence of metallurgical variables on environment-sensitive cracking of austenitic alloys. Int. Met. Rev. 2016, 24, 85-135.

3. Cihal, V. Intergranular corrosion of steels and alloys. Mater. Sci. Monogr. 1984, 18, 79.

4. ASTM G108-94: Standard Test Method for Electrochemical Reactivation (EPR) for Detecting Sensitization of AISI Type 304 and 304L Stainless Steels; ASTM: West Conshohocken, PA, USA, 2010.

5. Bühler, H.E.; Gerlach, L.; Greven, O.; Bleck, W. The electrochemical reactivation test (ERT) to detect the susceptibility to intergranular corrosion. Corros. Sci. 2003, 45, 2325-2336. [CrossRef]

6. Shaikh, H.; Sivaibharasi, N.; Sasi, B.; Anita, T.; Amirthalingam, R.; Rao, B.P.C.; Jayakumar, T. Use of eddy current testing method in detection and evaluation of sensitisation and intergranular corrosion in austenitic stainless steels. Corros. Sci. 2006, 48, 1462-1482. [CrossRef]

7. Garcia, C.; De Tiedra, M.P.; Blanco, Y.; Martin, O.; Martin, F. Intergranular corrosion of welded joints of austenitic stainless steels studied by using an electrochemical minicell. Corros. Sci. 2008, 50, 2390-2397. [CrossRef]

8. Pujar, M.G.; Parvathavarthini, N.; Dayal, R.K.; Thirunavukkarasu, S. Assessment of intergranular corrosion (IGC) in 316(N) stainless steel using electrochemical noise (EN) technique. Corros. Sci. 2009, 51, 1707-1713. [CrossRef]

9. Sahlaoui, H.; Makhlouf, K.; Sidhom, H.; Philibert, J. Effects of ageing conditions on the precipitates evolution, chromium depletion and intergranular corrosion susceptibility of AISI 316L: Experimental and modelling results. Mater. Sci. Eng. A 2004, 372, 98-108. [CrossRef]

10. Trillo, E.A.; Murr, L.E. Effects of carbon content, deformation and interfacial energetics on carbide precipitation and corrosion sensitization in 304 stainless steel. Acta Mater. 1998, 47, 235-245. [CrossRef]

11. Ralston, K.D.; Birbilis, N. The Effect of Grain Size on Corrosion: A Review. MRS Proc. 2010, 66, 075005. [CrossRef]

12. Li, S.X.; He, Y.N.; Yu, S.R.; Zhang, P.Y. Evaluation of the effect of grain size on chromium carbide precipitation and intergranular corrosion of 316L stainless steel. Corros. Sci. 2013, 66, 211-216. [CrossRef]

13. Yu, X.; Chen, S.; Wang, L. Effect of solution treatment conditions on the sensitization of austenitic stainless steel. J. Serbian Chem. Soc. 2009, 74, 1293-1302. [CrossRef]

14. Hall, E.L.; Briant, C.L. Chromium Depletion in the Vicinity of Carbides in Sensitized Austenitic Stainless Steels. Metall. Trans. A Phys. Metall. Mater. Sci. 1984, 15A, 793-811. [CrossRef]

15. Was, G.S.; Kruger, R.M. A thermodynamic and kinetic basis for understanding chromium depletion in Ni-Cr-Fe alloys. Acta Metall. 1985, 33, 841-854. [CrossRef]

16. Sahlaoui, H.; Sidhom, H.; Philibert, J. Prediction of chromium depleted-zone evolution during aging of Ni-Cr-Fe alloys. Acta Mater. 2002, 50, 1383-1392. [CrossRef]

17. Stawström, C.; Hillert, M. An Improved Depleted-zone Theory of Intergranular Corrosion of 18-8 Stainless Steel. J. Inron Steel Inst. 1969, 207, 77-85.

18. Pascali, R.; Benvenuti, A.; Wenger, D. Carbon content and grain size effects on the sensitization of AISI type 304 stainless steels. Corrosion 1984, 40, 21-32. [CrossRef]

19. Yin, Y.F.; Faulkner, R.G. Model predictions of grain boundary chromium depletion in Inconel 690. Corros. Sci. 2007, 49, 2177-2197. [CrossRef]

20. Yin, Y.; Faulkner, R.G.; Moreton, P.; Armson, I.; Coyle, P. Grain boundary chromium depletion in austenitic alloys. J. Mater. Sci. 2010, 45, 5872-5882. [CrossRef]

21. Bachmann, F.; Hielscher, R.; Schaeben, H. Grain detection from $2 \mathrm{~d}$ and $3 \mathrm{~d}$ EBSD data-Specification of the MTEX algorithm. Ultramicroscopy 2011, 111, 1720-1733. [CrossRef]

22. SFS - EN ISO 12732:2008: Corrosion of Metals and Alloys - Electrochemical Potentiokinetic Reactivation Measurement Using the Double Loop Method (Based on Cihal's Method) (ISO 12732:2006); Finnish Standards Association: Helsinki, Finland, 2008.

23. Majidi, A.P.; Streicher, M.A. Double Loop Reactivation Method for Detecting Sensitization in AISI 304 Stainless Steels. Corrosion 1984, 40, 584-593. [CrossRef]

24. Borgenstam, A.; Höglund, L.; Ågren, J.; Engström, A. DICTRA, a tool for simulation of diffusional transformations in alloys. J. Phase Equilibria 2000, 21, 269-280. [CrossRef] 
25. Andersson, J.O.; Helander, T.; Höglund, L.; Shi, P.; Sundman, B. Thermo-Calc \& DICTRA, computational tools for materials science. Calphad Comput. Coupling Phase Diagr. Thermochem. 2002, 26, 273-312.

26. Lewis, M.; Hattersley, B. Precipitation of $\mathrm{M}_{23} \mathrm{C}_{6}$ in austenitic steels. Acta Metall. 1965, 13, 1159-1168. [CrossRef]

27. Larsson, H.; Reed, R.C. On the numerical simulation of diffusion-controlled reactions under local equilibrium conditions. Acta Mater. 2008, 56, 3754-3760. [CrossRef]

28. Kolli, S.; Ohligschläger, T.; Porter, D. Quantitative Prediction of Sensitization in Austenitic Stainless Steel Accounting for Multicomponent Thermodynamic and Mass Balance Effects. ISIJ Int. 2019, 59, 1330-1336. [CrossRef]

29. Sourmail, T.; Too, C.H.; Bhadeshia, H.K.D.H. Sensitisation and Evolution of Chromium-depleted Zones in $\mathrm{Fe}-\mathrm{Cr}-\mathrm{Ni}-\mathrm{C}$ Systems. ISIJ Int. 2003, 43, 1814-1820. [CrossRef]

30. Kolli, S.; Ohligschläger, T.; Kömi, J.; Porter, D. Sensitization and Self-healing in Austenitic Stainless Steel: Quantitative Prediction Considering Carbide Nucleation and Growth. ISIJ Int. 2019. [CrossRef]

31. Parvathavarthini, N.; Dayal, R.K. Influence of chemical composition, prior deformation and prolonged thermal aging on the sensitization characteristics of austenitic stainless steels. J. Nucl. Mater. 2002, 305, 209-219. [CrossRef]

32. Agrawal, H.; Sharma, P.; Tiwari, P.; Taiwade, R.V.; Dayal, R.K. Evaluation of Self-Healing Behaviour of AISI 304 Stainless Steel Evaluation of Self-Healing Behaviour of AISI 304 Stainless Steel. Trans. Indian Inst. Met. 2015, 68, 501-511. [CrossRef]

33. Pond, R.C. Review of the principal contrast effects observed at interphase boundaries using transmission electron microscopy. J. Microsc. 1984, 135, 213-240. [CrossRef]

34. Trillo, E.; Murr, L. A TEM investigation of $\mathrm{M}_{23} \mathrm{C}_{6}$ carbide precipitation behaviour on varying grain boundary misorientations in 304 stainless steels. J. Mater. Sci. 1998, 33, 1263-1271. [CrossRef]

35. Bruemmer, S.M. Quantitative measurement and modelling of sensitization development in stainless steels. Corrosion 1990, 46, 556-562. [CrossRef]

(C) 2019 by the authors. Licensee MDPI, Basel, Switzerland. This article is an open access article distributed under the terms and conditions of the Creative Commons Attribution (CC BY) license (http://creativecommons.org/licenses/by/4.0/). 